\title{
PEMBUATAN DAN ANALISIS EXCITER GENERATOR RF UNTUK SIKLOTRON PROTON DECY-13
}

\author{
Prajitno \\ Pusat Teknologi Akselerator dan Proses Bahan, BATAN \\ Jl.Babarsari Kotak Pos 6101 Ykbb, Yogyakarta 55281 \\ e-mail: prajit@batan.go.id
}

Diterima 18 Mei 2011, diterima dalam bentuk perbaikan 19 Juli 2011, disetujui 19 Agustus 2011

\begin{abstract}
ABSTRAK
PEMBUATAN DAN ANALISIS EXCITER GENERATOR RF UNTUK SIKLOTRON PROTON DECY-13. Telah dilakukan analisis dan pembuatan exciter generator RF untuk siklotron proton $13 \mathrm{MeV}$. Generator RF akan digunakan sebagai sumber tegangan pemercepat bolak-balik siklotron DECY-13 rancangan PTAPBBATAN. Berdasarkan dokumen rancangan dasar yang telah dibuat siklotron Decy-13 akan menggunakan medan magnet 1,275 Tesla, sehingga frekuensi generator RF bila menggunakan harmonik keempat adalah 77,667 MHz. Salah satu teknik pembangkitan sinyal radio frekuensi untuk siklotron yang saat ini dikembangkan di dunia adalah dengan teknik Direct Digital Synthesizer (DDS). Teknologi DDS adalah sirkuit arsitektur inovatif yang memungkinkan manipulasi frekuensi dengan cepat dan tepat pada keluarannya dan sepenuhnya di bawah kontrol digital. Prototip exciter generator RF yang telah dibuat menggunakan DDS tipe AD9851 buatan Analog Device dengan frekuensi dasar $30 \mathrm{MHz}$. dan dikendalikan oleh mikrokontroler ATmega16. Untuk menghindari timbulnya frekuensi yang tidak diharapkan pada keluarannya, keluaran DDS dilewatkan rangkaian band pass filter pasif. Hasil pengujian menunjukkan bahwa rentang frekuensi keluaran exciter adalah $2 \mathrm{MHz}$ dengan frekuensi tengah 77,667 $\mathrm{MHz}$. dan stop band $-3 d B$. Sedangkan keluaran daya RF 10 Watt memerlukan catu daya $+12 \mathrm{~V}$ dengan arus 2,9 A. Meskipun prototip sudah berhasil dibuat dan hasilnya sesuai yang diharapkan, tetapi masih perlu disempurnakan.
\end{abstract}

Kata kunci: Exciter, generator RF, band pass filter, siklotron

\begin{abstract}
MANUFACTURE AND ANALYSIS OF EXCITER RF GENERATOR FOR PROTON CYCLOTRON $D E C Y-13$. Exciter of the RF generator for $13 \mathrm{MeV}$ proton cyclotron have been analyzed and manufactured. $R F$ generator will be used as a source of alternating voltage accelerating of the DECY-13 cyclotron which designed by PTAPB-BATAN. Based on the basic design documents that have been made, the Decy-13 cyclotron will use 1.275 Tesla magnetic field so that the RF generator frequency when using the fourth harmonic is $77.667 \mathrm{MHz}$. One of the radio frequency signal generation technique where the output frequency is very stable and easy to set up and is currently being developed is the technique of Direct Digital Synthesizer (DDS). DDS technology is an innovative circuit architecture that allows fast and precise frequency manipulation of its output, under full digital control. Prototype of the RF generator exciter that was created using DDS type AD9851 manufactured by Analog Devices with a fundamental frequency of $30 \mathrm{MHz}$ and controlled by the ATmega16 microcontroller. To avoid unexpected frequency of its output, the output signal of the DDS is passed to the passive band pass filter circuit. The test results showed that the exciter output frequency range is $2 \mathrm{MHz}$ with center frequency of $77.667 \mathrm{MHz}$. and stop band $-3 \mathrm{~dB}$. While RF power output 10 Watt require $+12 \mathrm{~V}$ power supply with current 1,6 A. Although the exciter prototype still needs improvement but the results are as expected.
\end{abstract}

Keywords: Exciter, RF generation, direct digital synthesizer, cyclotron

\section{PENDAHULUAN}

Sejalan dengan RPJMN 2010-2014 bidang Iptek, BATAN melaksanakan kegiatan prioritas bidang pembangunan Iptek yang terdiri atas prioritas bidang penguatan Sistem Inovasi Nasional (SIN) dan Peningkatan Penguasaan, Pengembangan dan Pemanfaatan Iptek (P3IPTEK) dengan fokus pembangunan 
tenaga nuklir dan radioisotop dalam rangka meningkatkan pemanfaatan energi nuklir, isotop dan radiasi di bidang pangan, energi, kesehatan dan obat serta sumber daya alam dan lingkungan yang berorientasi pada kebutuhan masyarakat. Dalam bidang kesehatan diharapkan menghasilkan keluaran antara lain berupa rancangan detil siklotron $13 \mathrm{MeV}$ untuk pembuatan radiofarmaka dan pengembangan obat.

Dalam upaya mendukung pengembangan teknologi akselerator saat ini di Pusat Teknologi Akselerator dan Proses Bahan Yogyakarta sedang melakukan kegiatan kajian perancangan siklotron proton dengan sasaran dapat diperoleh rancangan detil siklotron $13 \mathrm{MeV}$ dan prototipe Radio Frequency (RF) dan magnet.

Tujuan dari kegiatan pembuatan dan analisis prototip sistem generator RF adalah untuk merealisir rancangan dasar yang telah dibuat sebelumnya dengan memanfaatkan komponen dan modul elektronik yang ada di pasar lokal. Sasaran dari kegiatan ini adalah diperolehnya prototip generator RF yang terdiri dari exciter DDS, bandpass amplifier, drive amplifier dan final amplifier yang keluarannya digunakan untuk mencatu tegangan dee melalui RF coupler seperti blok diagram Gambar 1.

Bagian yang paling penting dari sistem generator RF adalah exciter karena pada bagian inilah stabilitas generator RF ditentukan, oleh karena itu pada makalah ini diuraikan pembuatan dan analisis prototip exciter yang menggunakan rangkaian terintegrasi DDS buatan Analog

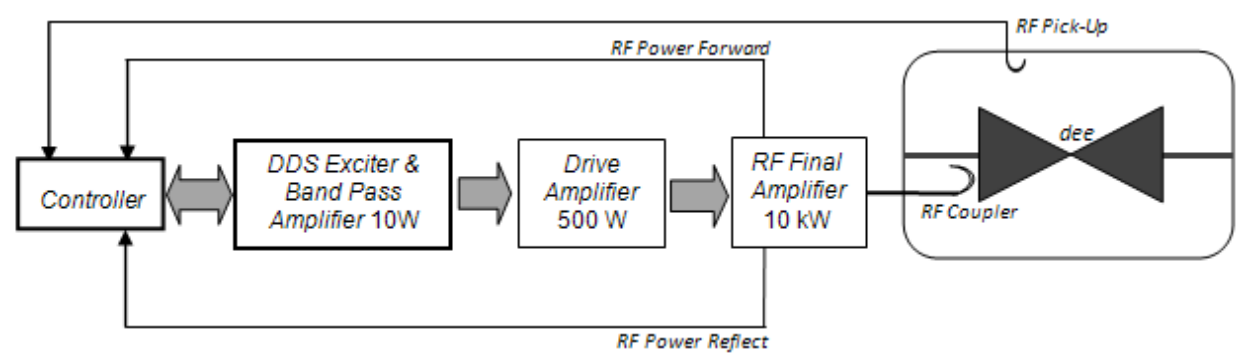

Gambar 1. Blok diagram sistem generator RF.

Device tipe AD9851 dengan sistem clock yang berasal dari rangkaian osilator kristal dan pengaturan frekuensi dilakukan oleh controller berbasis mikrokontroler. Sedangkan untuk mengantisipasi frekuensi ikutan yang keluar dari DDS digunakan band pass filter dengan frekuensi tengah 77,667 MHz. Keluaran band pass filter selanjutnya diumpankan ke penguat RF yang dapat mengeluarkan daya RF $10 \mathrm{~W}$.

\section{PRINSIP DASAR GENERATOR RF}

Siklotron mempercepat ion secara periodik dengan menggunakan tegangan pemercepat bolak-balik yang dipasang pada dua buah elektrode berongga yang dihampakan sehingga dapat dilintasi oleh berkas ion. Dengan medan magnet yang kuat timbul gaya Lorenz yang merupakan gaya sentripetal pada berkas ini sehingga lintasannya melingkar dan dapat dipercepat berulang-ulang setiap kali melalui celah di antara kedua elektrode yang disebut Dee. Catu tegangan pemercepat bolak-balik dibangkitkan oleh generator Radio Frequency (RF) yang frekuensinya ( $f$ ) dapat dihitung menggunakan persamaan sebagai berikut: ${ }^{(1)}$

$$
\begin{aligned}
f_{\text {ion }} & =\frac{q B_{0}}{2 \pi M_{0}} \\
f_{\text {rf }} & =h \times f_{\text {ion }}
\end{aligned}
$$

Keterangan :

$$
\begin{array}{lll}
q & : & \text { muatan partikel berkas } \\
B_{0} & : & \text { kuat medan magnet } \\
M_{0}: & \text { massa partikel bebas proton } \\
h & : & \text { nomor harmonik }
\end{array}
$$

Hasil kajian perhitungan medan magnet untuk siklotron $13 \mathrm{MeV}$ DECY-13 telah dilakukan, siklotron akan menggunakan medan magnet rerata $\left(B_{0}\right)$ 1,275 Tesla dan nomor harmonik $4{ }^{(2)}$. Selain itu berdasar referensi dari Handbook of Accelerator Physics and Engineering ${ }^{(1)}$ muatan partikel berkas $q=1,602 \mathrm{E}^{-19}$ coulomb dan massa 
partikel bebas proton $M_{0}=1,673 \mathrm{E}-27 \mathrm{~kg}$. Oleh karena itu frekuensi yang akan digunakan untuk siklotron DECY13 dapat dihitung menggunakan persamaan (1) dan (2) sebagai berikut :

$$
\begin{array}{rlr}
f_{\text {ion }} & =\frac{1,6 \times 10^{-19} \times 1,275}{2 \times 2,141 \times 1,673^{-27}} & \mathrm{~Hz} \\
& =1,9417 \times 10^{7}=19,417 & \mathrm{MHz} \\
f_{r f} & =4 \times 19,417=77,667 & \mathrm{MHz}
\end{array}
$$

\section{AD9851}

AD9851 ${ }^{(3,4)}$ adalah perangkat sangat terintegrasi yang menggunakan teknologi terdepan DDS, digabung dengan pengubah D/A internal kecepatan dan kinerja tinggi dan pembanding, untuk membentuk sintesis frekuensi yang diprogram secara digital. Ketika diberi referensi dari sumber clock akurat, AD9851 menghasilkan keluaran gelombang sinus analog yang frekuensinya stabil. AD9851 menerima 32 bit frekuensi tuning word, yang menghasilkan keluaran resolusi pengatur sekitar $0,04 \mathrm{~Hz}$ dengan sistem clock $180 \mathrm{MHz}$. AD9851 berisi sirkuit pengali REFCLK $6 \times$ yang menghilangkan kebutuhan untuk referensi osilator kecepatan tinggi dan memiliki dampak minimal pada Spurious Free Dynamic Range (SFDR) dan fase karakteristik derau (noise).

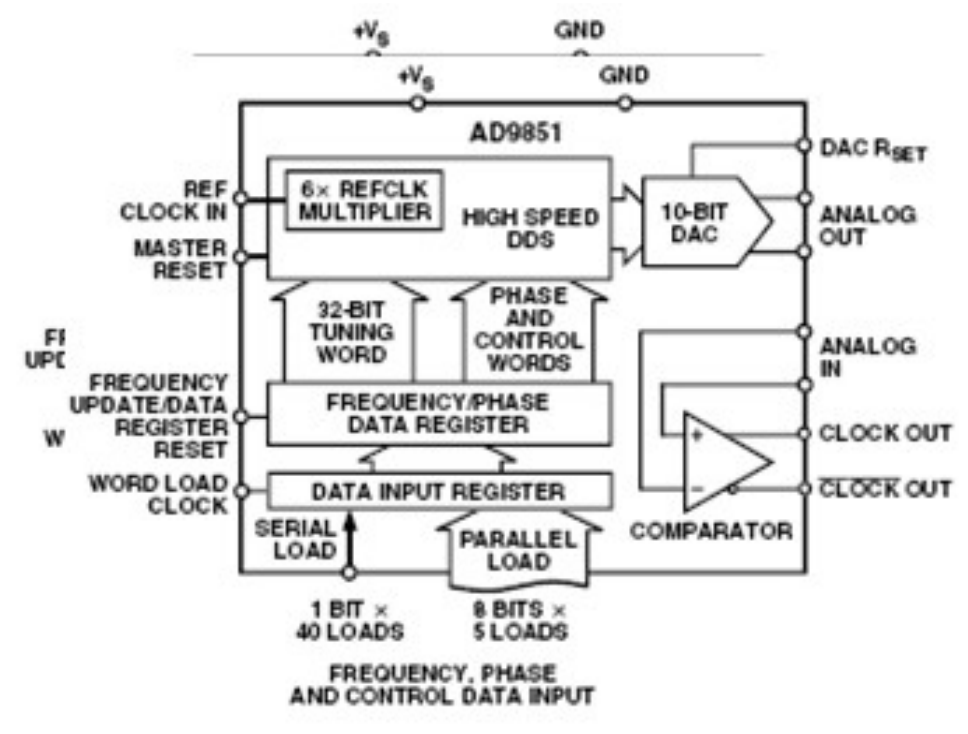

Gambar 2. Blok diagram fungsi AD9851

Pada Gambar 2 terlihat blok diagram fungsi dari DDS AD9851, pengaturan frekuensi dan fase keluaran dapat dilakukan dengan memasukkan data ke data input register secara serial atau parallel. Apabila memasukkan data secara serial maka data yang perlu dimuat adalah 1 bit x 40 sedangkan bila memasukkan data secara parallel 8 bit $\times 5$. Ref Clock In menerima masukan dari osilator kristal. Urutan data yang harus dimuat ke data input register seperti tertampil pada Gambar 3.

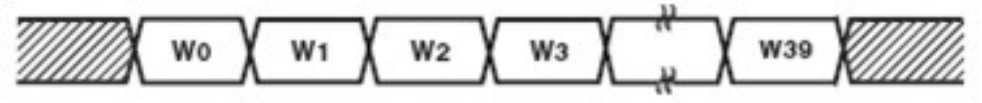

Gambar 3. Runtunan data serial yang dimuat ke data input register DDS AD9851

\section{Perhitungan Frekuensi Keluaran AD9851}

Keluaran frekuensi dari perangkat DDS AD9851 ditentukan dengan persamaan: ${ }^{(3,4)}$

$$
f_{\text {out }}=\frac{M \times f_{\text {out }} \times \operatorname{Re} f C l k}{2^{N}}
$$




$$
M=\frac{f_{\text {out }} \times 2^{N}}{\operatorname{Re} f C l k}
$$

Keterangan :

$$
\begin{array}{lll}
f_{\text {out }} & : & \text { frekuensi keluaran dari DDS } \\
M & : & \text { frequency tuning word } \\
\text { RefClk } & : & \text { referensi internal frekuensi clock } \\
N & : & \text { panjang dalam bit dari akumulator fasa }
\end{array}
$$

Sesuai dengan perhitungan, frekuensi yang akan digunakan untuk siklotron DECY-13 adalah 77,667 MHz., dengan menggunakan persamaan (4) dapat ditentukan nilai yang harus dimasukkan ke dalam frequency control dari DDS.

Selain frekuensi utama yang sesuai rancangan, keluaran frekuensi DDS juga disertai dengan frekuensi lain yang merupakan gabungan dari frekuensi keluaran $\left(f_{1}\right)$ dan frekuensi clock $\left(f_{2}\right)$. Frekuensi tersebut diantaranya $f_{2}-f_{1}, f_{2}-2 f_{1}, 2 f_{2}-3 f_{1}$ dan $2 f_{1}{ }^{(5)}$. Guna meminimalkan pengaruh frekuensi yang tidak diharapkan tersebut maka keluaran DDS dilewatkan rangkaian band pass filter dengan sasaran hanya frekuensi yang diinginkan saja yang muncul pada keluaran DDS.

\section{FILTER}

\section{Low Pass Filter (LPF)}

Low Pass Filter adalah filter yang hanya melewatkan frekuensi yang lebih rendah dari frekuensi cut-off $\left(f_{c}\right)$, di atas frekuensi tersebut keluarannya mengecil karena diberi redaman yang sangat besar.

\section{High Pass Filter (HPF)}

High Pass Filter adalah filter yang keluarannya hanya melewatkan frekuensi diatas frekuensi cut-off $\left(\mathrm{f}_{\mathrm{c}}\right)$, di bawah frekuensi tersebut keluaran diredam sehingga idealnya menjadi tidak ada.

\section{Band Pass Filter (BPF)}

Band pass filter merupakan rangkaian filter yang hanya memperbolehkan frekuensi dengan rentang (band) tertentu untuk dapat melewatinya, dengan memberi redaman yang sangat besar pada frekuensi yang terlalu tinggi dan terlalu rendah. Sehingga rangkaian band pass filter memiliki dua frekuensi cut-off ( $f_{C H}$ dan $\left.f_{C L}\right)$ seperti tertampil pada Gambar 4.

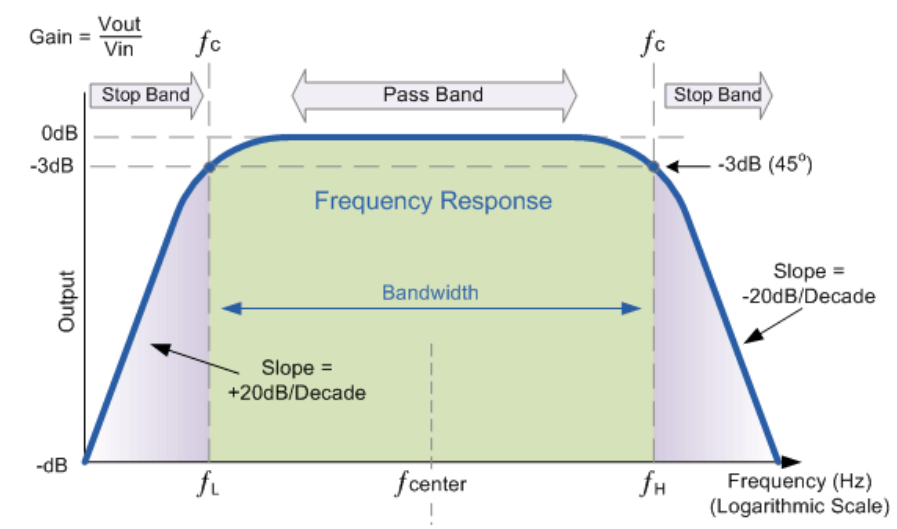

Gambar 4. Tanggapan gain vs frekuensi Band Pass Filter berikut :

Untuk menentukan nilai-nilai kapasitan dan induktan pada band pass filter digunakan persamaan sebagai

$$
f_{\text {center }}=\sqrt{f_{L} f_{H}}
$$




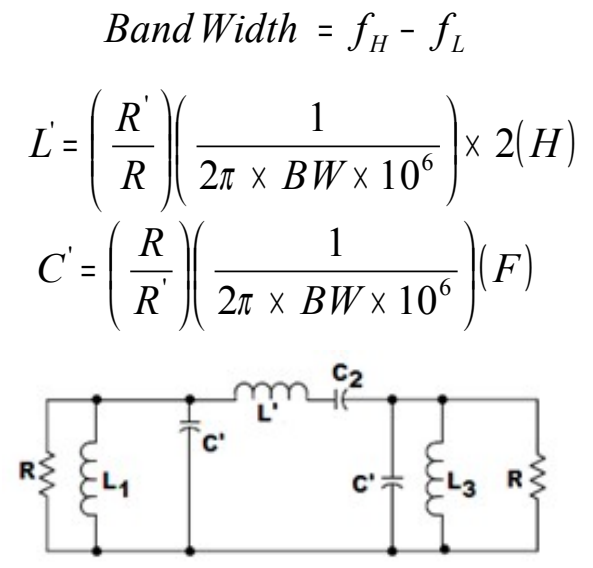

Gambar 5. Rangkaian band pass filter

$$
\begin{gathered}
C_{2}=\frac{1}{L^{\prime}\left(2 \pi \times f_{0}\right)^{2}} \\
L_{1}=L_{2}=\frac{1}{C^{\prime}\left(2 \pi \times f_{0}\right)^{2}}
\end{gathered}
$$

\section{Mikrokontroler ATmega16}

AVR merupakan seri mikrokontroler CMOS 8-bit buatan Atmel, berbasis arsitektur RISC (Reduced Instruction Set Computer). Hampir semua instruksi dieksekusi dalam satu siklus clock. AVR mempunyai 32 register general-purpose, timer/counter fleksibel dengan mode compare, interrupt internal dan eksternal, serial UART, programmable Watchdog Timer, dan mode power saving, ADC dan PWM internal. AVR juga mempunyai In-System Programmable Flash on-chip yang mengijinkan memori program untuk diprogram ulang dalam system menggunakan hubungan serial SPI. ATMega16.

\section{TATA KERJA}

\section{Bahan dan Alat Penelitian}

Bahan dan alat yang digunakan dalam penelitian pembuatan exciter ini adalah sebagai berikut

1. IC AD9851 beserta pendukungnya yaitu kapasitor, resistor dan induktor

2. Kristal $30 \mathrm{MHz}$.

3. Modul catu daya linier $12 \mathrm{~V}$ dan catu daya switching $12-13,8 \mathrm{~V}$

4. Modul penguat RF 10 Watt

5. Modul mikrokontroller

6. Oscilloscope

7. Spectrum Analyzer

8. Digital Multimeter

9. Soldering Iron

10. SMD rework station

\section{Susunan Exciter Generator RF DECY-13}

Pembuatan exciter generator RF dengan susunan seperti terlihat pada Gambar 6, terdiri dari modul mikrokontroler ATmega16 yang berfungsi untuk mengatur frekuensi dan fase keluaran DDS, DDS AD9851 yang dilengkapi osilator kristal $30 \mathrm{MHz}$, Band Pass Filter dan penguat RF. 


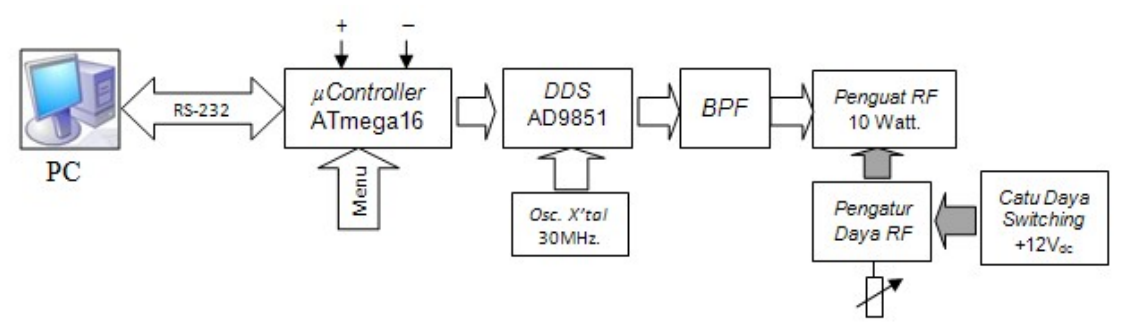

Gambar 6. Blok diagram exciter generator RF

\section{HASIL DAN PEMBAHASAN}

Prototip exciter generator RF untuk siklotron DECY-13 telah selesai dibuat dengan tata letak modul elektronik sebagai tertampil pada Gambar 7.

Modul-modul elektronik yang telah diinstal adalah :

1. Catu daya linier $\pm 12 \mathrm{~V}_{\mathrm{dc}}$ untuk mencatu rangkaian elektronik modul DDS, mikrokontroler dan osilator kristal $30 \mathrm{MHz}$.

2. Catu daya switching $+12 \mathrm{~V}_{\mathrm{dc}}$ digunakan untuk mencatu tegangan penguat $\mathrm{RF} 10 \mathrm{~W}$

3. Osilator kristal $30 \mathrm{MHz}$. sebagai frekuensi referensi DDS

4. DDS AD9851 dan band pass filter

5. ATmega16 untuk mengatur kinerja DDS AD9851

6. Penguat RF dengan keluaran maksimum 10 Watt

7. Pengatur keluaran daya RF dan Automatic Level Control penguat RF

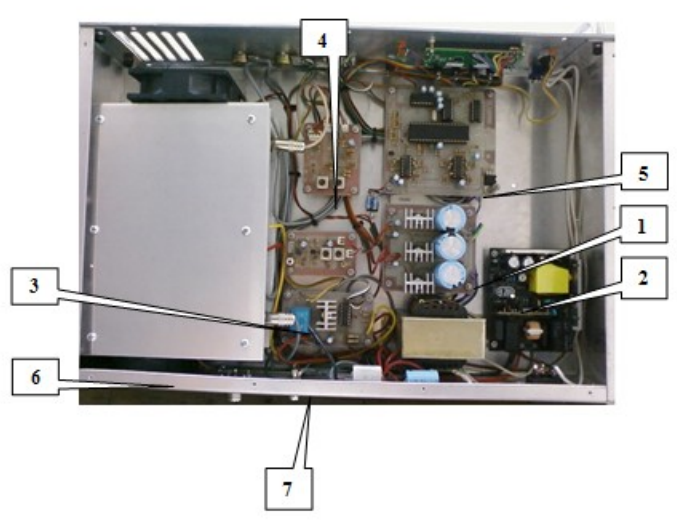

Gambar 7. Tata letak prototip exciter generator RF

Panel depan prototip exciter generator RF seperti terlihat pada Gambar 8, terdapat tombol, knop, konektor, tampilan LCD dan LED dengan penjelasan fungsi sebagai berikut :

1. Switch ON/OFF dan fuse pengaman

2. Tombol untuk mengubah frekuensi turun $(-)$ atau naik (+)

3. Tombol untuk pemilihan menu software

4. Liquid Crystal Display ( $L C D)$ untuk menampilkan frekuensi

5. Indikator trip:

- CURR (arus penguat RF)

- VDD (tegangan penguat RF)

- REFL (Refected power)

- TEMP (suhu pendingin penguat RF) dan

- Tombol reset.

6. Konektor DB-9 untuk komunikasi data serial komputer dengan baud rate 1200-19200.

7. Knop untuk mengatur keluaran daya RF secara manual 
8. Knop untuk mengatur Automatic Level Control

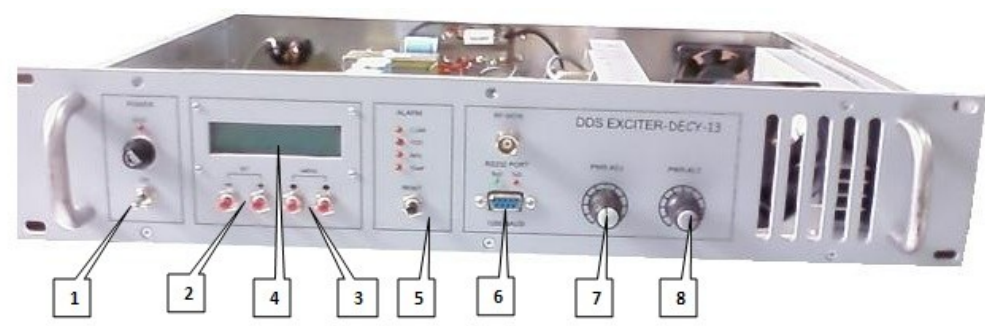

Gambar 8. Tampilan panel depan prototip exciter

Panel belakang untuk fasilitas masukan tegangan catu 220 Vac, masukan $A L C$ dan keluaran RF, seperti terlihat pada Gambar 9.

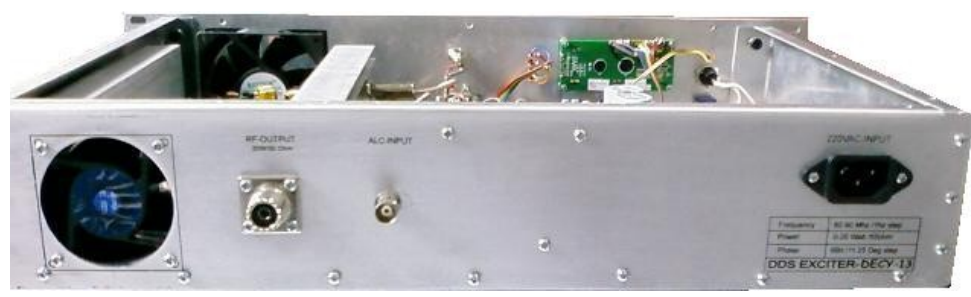

Gambar 9. Tampilan panel belakang prototip exciter

\section{Frekuensi referensi $30 \mathrm{MHz}$.}

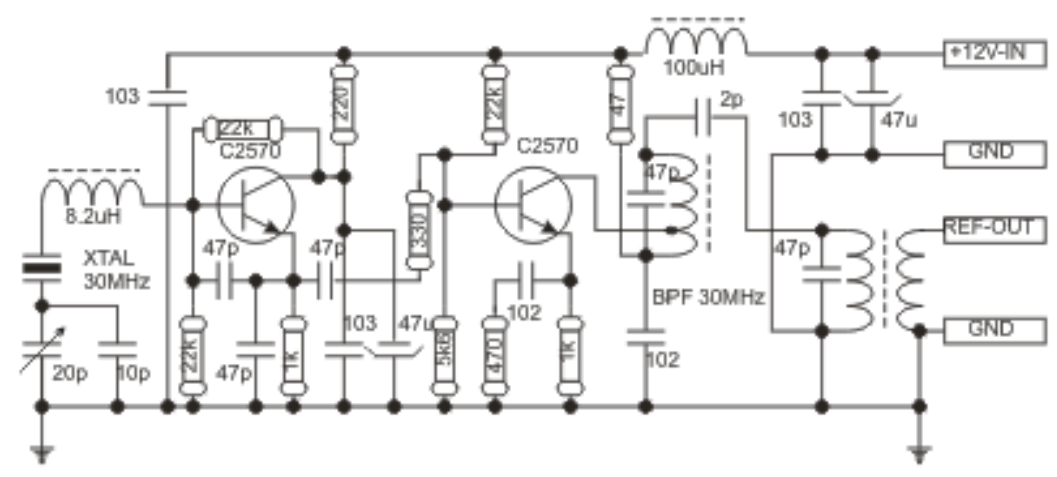

Gambar 10. Rangkaian elektronik frekuensi referensi $30 \mathrm{MHz}$.

Frekuensi referensi DDS AD9851 dibangkitkan dari osilator kristal $30 \mathrm{MHz}$, kristal yang digunakan adalah tipe $\mathrm{HC} 494 / \mathrm{AH}$ dengan stabilitas frekuensi $\pm 50 \mathrm{ppm}$. Untuk menghindari munculnya frekuensi harmonik keluaran osilator dilewatkan rangkaian band pass filter $30 \mathrm{MHz}$. sehingga frekuensi yang masuk ke DDS AD9851 hanya yang sesuai kristal.

\section{Pengaturan Frekuensi Keluaran DDS}

Pengaturan frekuensi keluaran $77,667 \mathrm{MHz}$ dilakukan dengan mengirimkan data secara serial melalui pin-7 DDS AD9851, data frequency tuning word yang harus dikirimkan dihitung menggunakan persamaan (4) yaitu : $M=\frac{77,667 \times 2^{32}}{180}$

$\mathrm{M}=1853206805_{\mathrm{D}} \rightarrow 01101110011101011011000100010101_{\mathrm{B}}$

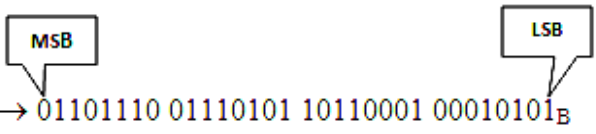




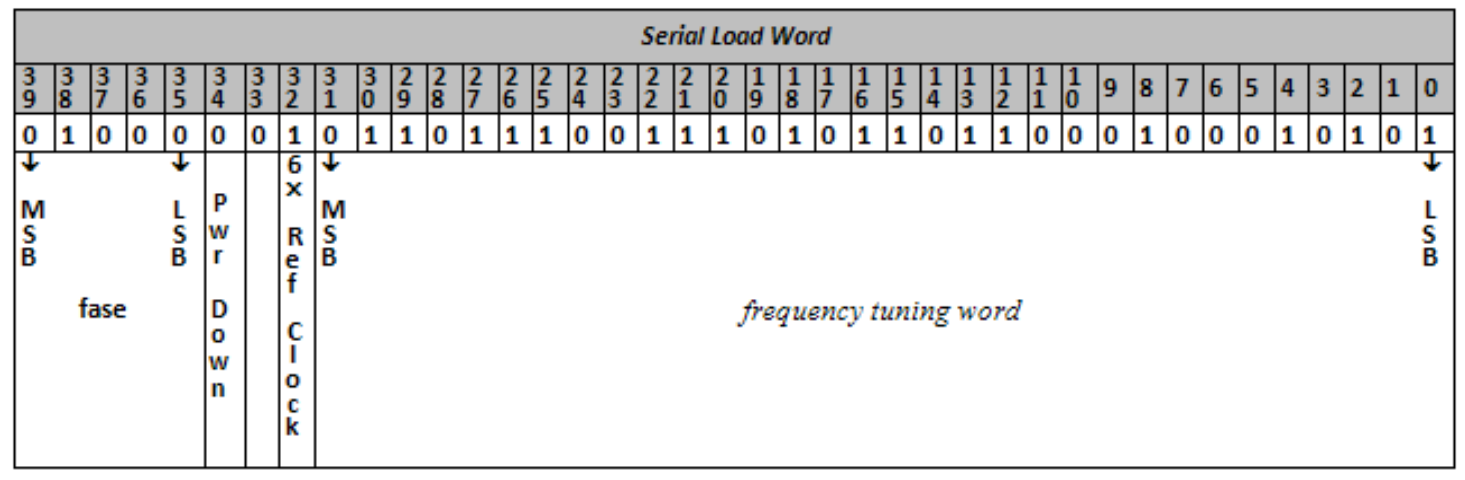

Gambar 10. Runtunan data untuk frekuensi $77,667 \mathrm{MHz}$.

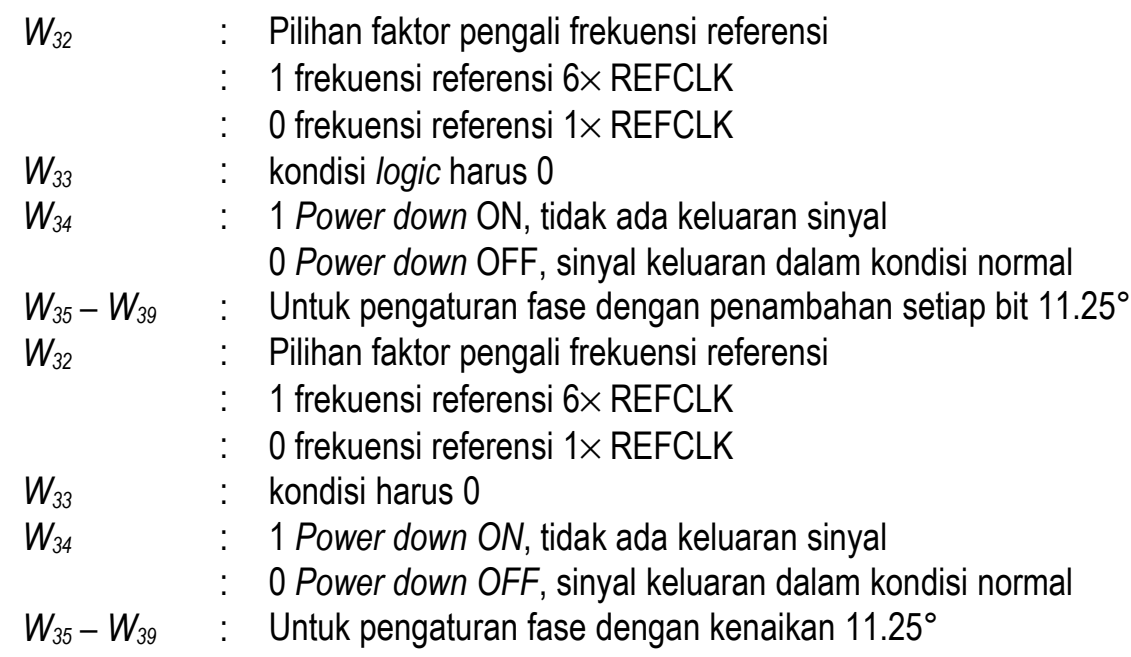

Data dalam bentuk runtunan bit inilah yang harus dimuat dalam data input register secara serial untuk menentukan frekuensi keluaran DDS dengan panjang 32 bit, dengan urutan mulai LSB dan terakhir MSB atau dari kiri ke kanan atau mulai $W_{0}$ dan berakhir dengan $W_{31}$, seperti tertampil pada Gambar 10 . Sisa 8 bit yaitu bit ke 32 sampai bit 39 digunakan untuk mengatur pilihan frekuensi referensi AD9851, power-down dan fase. Pengaturan fase dimulai dari LSB dan berakhir pada bit LSB. Posisi runtunan bit yang dimuat ke data input register untuk frekuensi 77,667 MHz seperti ditampilkan pada Gambar 10.

\section{Pengamatan Frekuensi Keluaran Exciter DDS AD9851}

Pengamatan frekuensi keluaran dilakukan menggunakan Spectrum Analyzer Hameg-5012. Spektrum frekuensi keluaran exciter DDS AD9851 seperti tertampil pada Gambar 11, nampak bahwa selain frekuensi yang diharapkan yaitu $77,667 \mathrm{MHz}$ juga muncul frekuensi lain yang merupakan selisih atau kelipatan dari frekuensi clock DDS $\left(f_{2}\right)$ dan frekuensi keluaran exciter yang diharapkan $\left(f_{1}\right)$ antara lain :

$$
\begin{array}{llll}
f_{1} & =77,667 \mathrm{MHz} . \quad(-2,84 \mathrm{~dB}) & & \\
f_{2} & =180,000 \mathrm{MHz} .(\text { referensi) } & & \\
f_{2}-f_{1} & =180-77,667 & =102,333 \mathrm{MHz} . & (-5,24 \mathrm{~dB}) \\
2 f_{1} & =2 \times 77,667 & =155,334 \mathrm{MHz} . & (-52,65 \mathrm{~dB}) \\
f_{2}-2 f 1=180-(2 \times 77,667) & =24,666 \mathrm{MHz} . & (-55,24 \mathrm{~dB}) \\
2 f_{2}-3 f_{1}=(2 \times 180)-(3 \times 77,667) & =126,999 \mathrm{MHz} & (-64,86 \mathrm{~dB})
\end{array}
$$




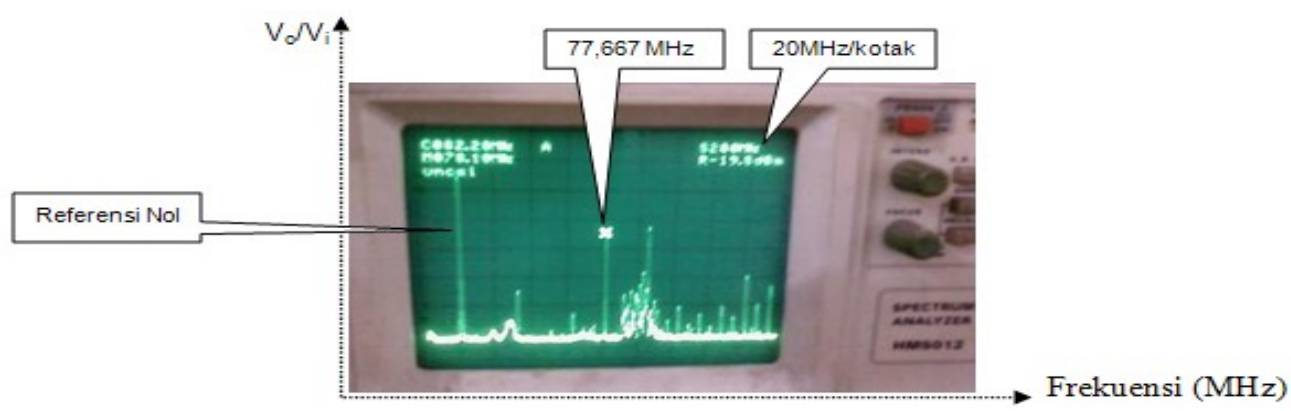

Gambar 11. Spektrum frekuensi keluaran exciter DDS AD9851

Pada Gambar 11 tampilan spektrum frekuensi diatur satu kotak $=20 \mathrm{MHz}$. dan pada bagian kiri spektrum yang paling tinggi adalah frekuensi referensi, terlihat pada layar spektrum yang diberi tanda $\mathbf{x}$ adalah frekuensi yang diharapkan yaitu $77,667 \mathrm{MHz}$, sedangkan frekuensi lainnya harus diredam menggunakan bandpass filter.

\section{Bandpass Filter}

Untuk menghindari munculnya frekuensi-frekuensi yang tidak diharapkan pada keluaran exciter, keluaran DDS AD9851 perlu dilewatkan rangkaian band pass filter dengan tujuan meredam frekuensi-frekuensi yang tidak diharapkan. Dengan menggunakan persamaan $(5,6,7,8,9,10)$ dapat diperoleh nilai-nilai kapasitor dan induktor seperti yang tertampil pada Gambar 12. Nilai kapasitan diambil menggunakan standar nilai komponen yang ada di pasaran, oleh karena itu untuk mengkompensasi agar (stop band) $L_{L}$ dan (stop band) ${ }_{H}$ dapat dipenuhi sesuai dengan rancangan maka digunakan induktor yang nilai induktansinya dapat diubah.

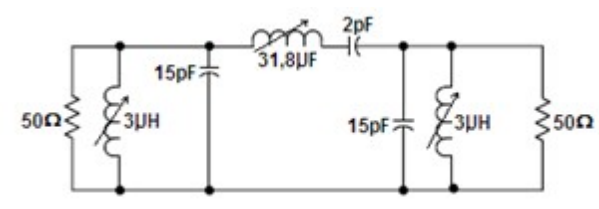

Gambar 12. Band pass filter untuk rentang frekuensi $76,667-78,667 \mathrm{MHz}$.

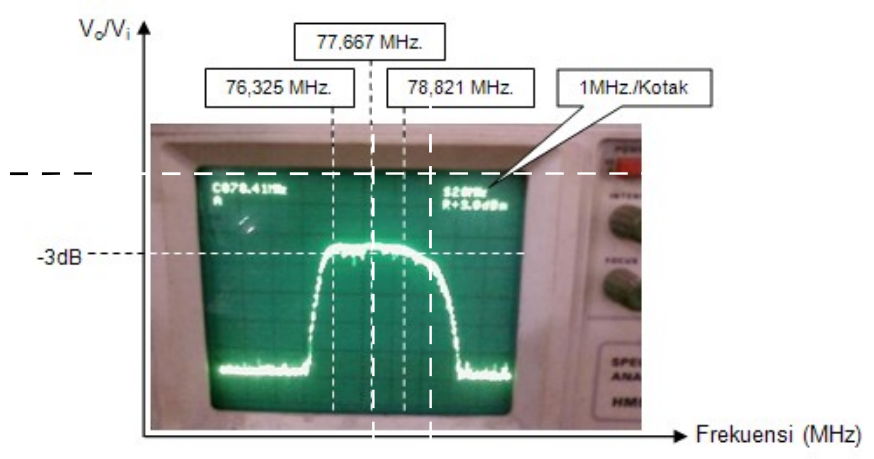

Gambar 13. Keluaran exciter gain vs frekuensi (MHz)

Hasil pengamatan band pass filter menggunakan spectrum analyzer dengan frekuensi tengah $77,667 \mathrm{MHz}$. dan standar $f_{\text {cut-off }}-3 \mathrm{~dB}$ diperoleh $f_{\text {cut-off bawah }}=76,325 \mathrm{MHz}$ dan $f_{\text {cut-off atas }}=78,821 \mathrm{MHz}$ seperti ditampilkan pada Gambar 13. Terjadi penyimpangan pass band sebesar $0,249 \mathrm{MHz}$ dibandingkan dengan rancangan, hal ini kemungkinan disebabkan oleh toleransi dari komponen yang digunakan dan kurang tepatnya pengaturan induktansi.

Pada Gambar 14 dapat dilihat bahwa frekuensi-frekuensi yang tidak diperlukan sudah teredam $(\leq-49$ $\mathrm{dBm})$ dan yang muncul adalah frekuensi $77,667 \mathrm{MHz}$. (-2,6 dBm) yang menjadi masukan penguat RF. Namun hasil ini masih perlu ditingkatkan karena untuk mencatu sumber daya pemercepat ion, selain frekuensinya harus sangat stabil, bandwidth-nya juga harus sesempit mungkin agar daya yang disalurkan ke sistem dee menjadi efisien. 


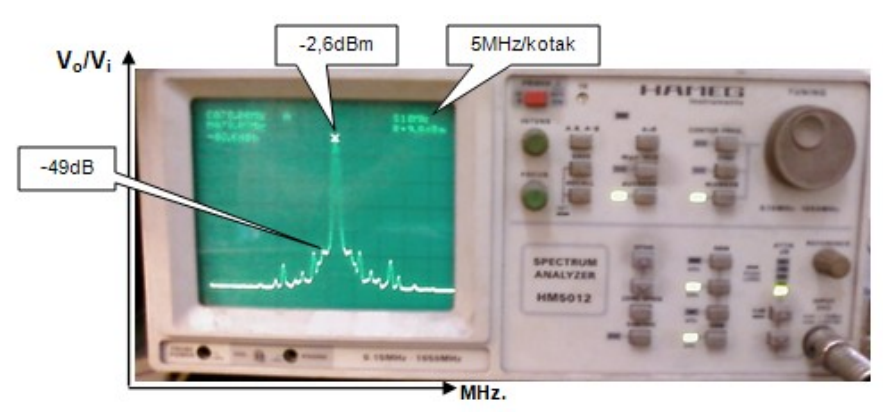

Gambar 14. Frekuensi vs penguatan keluaran penguat RF

\section{Modul penguat RF}

Modul penguat RF menerima masukan dari keluaran DDS setelah dilewatkan band pass filter, dari hasil pengujian untuk keluaran daya 10 Watt diperlukan tegangan $+12 \mathrm{~V}$ dengan arus diperlukan arus $\pm 2,9 \mathrm{~A}$.

Dalam mengoperasikan modul penguat RF, panas yang terjadi pada pendingin dibatasi tidak boleh lebih dari $40{ }^{\circ} \mathrm{C}$. Oleh karena itu pada pendingin penguat RF dipasang detektor suhu menggunakan LM-35 buatan National Instrument dengan catu daya $12 \mathrm{~V}_{\mathrm{dc}}$. LM-35 adalah rangkaian sensor suhu terintegrasi, linier dan presisi dengan fitur $+10.0 \mathrm{mV} /{ }^{\circ} \mathrm{C}^{(6)}$. Sehingga untuk untuk mendeteksi suhu $40^{\circ} \mathrm{C}$ akan diperoleh tegangan keluaran dari LM-35 sebesar $400 \mathrm{mV}$. Tegangan keluaran LM-35 ini akan dibaca oleh mikrokontroler dan ditampilkan pada layar LCD. Apabila suhu pendingin penguat RF melebihi $40{ }^{\circ} \mathrm{C}$ penguat RF akan diamankan sehingga terhindar dari kerusakan.

\section{Pengukuran frekuensi}

Pengukuran frekuensi dilakukan menggunakan GW Intelligent Counter GFC-8131, pada saat frekuensi keluaran exciter diprogram $77,667 \mathrm{MHz}$, tampilan frekuensi pada frequency counter menunjuk $77,667063 \mathrm{MHz}$ seperti tampilan Gambar 15. Dengan demikian terjadi perbedaan $63 \mathrm{~Hz}$. Perbedaaan ini terjadi dikarenakan kristal untuk frekuensi referensi menggunakan kristal yang belum ada kompensasi suhu lingkungan. Oleh karena itu sedang diusahakan mendapatkan kristal yang sudah dilengkapi dengan kompensasi suhu yaitu kristal tipe Temperature Compensated Crystal (TCXO), sehingga tidak terjadi selisih antara frekuensi yang diprogram dengan hasil pengukuran frequency counter.

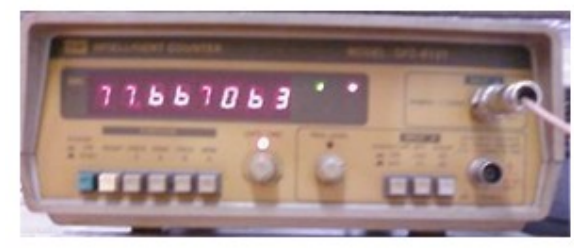

Gambar 15. Tampilan frekuensi pada saat exciter diprogram $77,667 \mathrm{MHz}$

\section{PERANGKAT LUNAK}

Modul mikrokontroler ATmega16 perangkat lunak pendukungnya dikembangkan menggunakan VMLAB. VMLAB (Visual Micro Lab) adalah sebuah virtual protyping IDE yang menggabungkan IDE, Assembler, Compiler, Debugger, dan simulator serta dapat mensimulasikan hardware (komponen elektronik).

Perangkat lunak telah dibuat dan sudah diuji unjuk kerjanya untuk mengatur beroperasinya exciter generator RF dan diperoleh hasil yang baik sesuai dengan rancangan. Fungsi perangkat lunak dibuat dalam bentuk menu pilihan yang dapat dipilih menggur artombol, (callouts 2) dan untuk mengubah nilai menggunakan tombol + atau - (callouts 3) yang ada di panel depan (Gambar 8.). Menu pilihan ada 10 fungsi yaitu :

1. DDS freq frekuensi keluaran exciter dapat diatur dengan step sesuai pilihan-2 seperti contoh pada Gambar 16. 


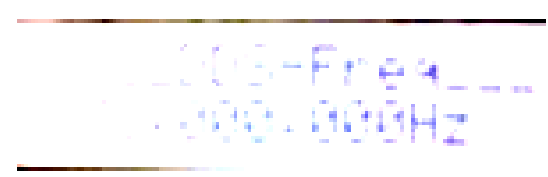

Gambar 16. Contoh tampilan LCD

2. DDS-step

Pilihan: $1000 \mathrm{kHz}$.

$100 \mathrm{kHz}$.

$10 \mathrm{kHz}$.

$1 \mathrm{kHz}$.

$100 \mathrm{~Hz}$.

$10 \mathrm{~Hz}$

$1 \mathrm{~Hz}$

3. DDS-phase pengaturan fase dengan step $11,25^{\circ}$

4. DDS-Ref $6 \times$ frekuensi referensi $=180.000 .000 \mathrm{~Hz}$.

5. Current maksimum arus penguat RF 5A

6. Vcc maksimum tegangan penguat RF 13,8 V

7. Reflect maksimum daya RF yang tidak tersalurkan $2,64 \mathrm{~W}$

8. Forwardmaksimum daya RF keluaran exciter $10,0 \mathrm{~W}$

9. Temp suhu pendingin ditentukan maksimum $40{ }^{\circ} \mathrm{C}$

10. DDS PWR Control

- PWR UP posisi default

- PWR DOWN tidak ada keluaran frekuensi

\section{KESIMPULAN}

Telah selesai dibuat exciter generator RF untuk siklotron DECY-13 menggunakan teknik Direct Digital Synthesizer. Pemrograman frekuensi keluaran DDS dilakukan secara serial dengan memasukkan data melalui pin-7 AD9851 dengan panjang 40 bit mulai bit LSB dan berakhir pada bit MSB. Untuk menghindari frekuensi ikutan yang tidak diharapkan diantaranya selisih dan atau kelipatan frekuensi clock dari DDS dan frekuensi keluaran exciter, keluaran DDS dilewatkan rangkaian band pass filter dengan frekuensi tengah $77,667 \mathrm{MHz}$. dan rentang frekuensi $2,249 \mathrm{MHz}$.

Pada daya 10 Watt penguat RF memerlukan tegangan $D C+12 \mathrm{~V}$ dengan arus $\pm 2,9 \mathrm{~A}$. Untuk menghindari panas yang berlebih, pada penguat RF dipasang detektor suhu LM-35 yang digunakan sebagai masukan sistem pengaman.

Meskipun prototip sudah berhasil dibuat dan hasilnya sesuai yang diharapkan, tetapi masih perlu disempurnakan terutama mempersempit bandwidth keluaran exciter agar generator RF lebih efisien untuk mencatu sistem dee pada siklotron yang akan dibangun di BATAN.

\section{UCAPAN TERIMA KASIH}

Dengan selesainya pembuatan prototip exciter generator RF ini disampaikan ucapan terima kasih yang sebesar-besarnya kepada rekan-rekan komunitas IQED khususnya Sdr. Wardhana N. , Iwan dan Agus atas masukan dan ide-ide dalam merealisasikan prototip exciter.

\section{DAFTAR PUSTAKA}

ALEXANDER WU CHAO, MAURY TIGNER, Handbook of Accelerator Physics and Engineering, $2^{\text {nd }}$ Printing, Printed in Singapore, (2002)

PRAJITNO, "Perancangan Pembangkit Sinyal Sinusoida 78 Mhz. Dengan Teknik Direct Digital Synthesizer", Prosiding Pertemuan dan Presentasi IImiah Teknologi Akselerator dan Aplikasinya, Vol. 12, Yogyakarta, (2010) $90-97$ 
A. CARUSO, A. SPARTÀ, YIN ZHINGUO AND A. LONGHITANO, "Steps Forward in The Digital RF Control System at LNS", Proceedings of the $18^{\text {th }}$ International Conference on Cyclotrons and Their Applications, Giardini Naxos, Italy (2007) $476-478$

RUZAIRI ABDUL RAHIM, TEO CHIN HENG, S. SULAIMAN, M. S. ABDUL MANAF, Jurnal Teknologi, 45(D), Universiti Teknologi Malaysia (2006) $19-39$

DONG LI, TONGNING HU, LEI CAO, BIN QIN, JUN YANG, JIANG HUANG, "Design and Test of 10KW RF Amplifier Based On Direct Digital Synthesizer", Proceedings of the $23^{\text {rd }}$ Particle Accelerator Conference, Vancouver, BC, Canada (2009) 885-887

CAHYA EDI SANTOSA, ARI SUGENG BUDIYANTA, Jurnal Sains Dirgantara, Vol. 7 No. 1 (2009) 201-212 